\title{
TAKHRÎJ AL-HADÎTH DALAM PERSPEKTIF KAJIAN ONTOLOGI DAN AKSIOLOGI ILMU HADIS
}

\author{
Abdul Basid \\ Institut Agama Islam Bani Fattah Jombang, Indonesia \\ E-mail: quraishbasid@gmail.com
}

\begin{abstract}
In reading a hadith, it is not enough just to a dictionary and a book of hadith as a reference. This is because the hadith collected in many books of hadith. So as a takhrij al-hadith emerged as a method to track the tradition to the original source. Application of the method takhrij al-hadith has two major variants; conventional (sanad and matn) and modern (computer) . Two variants will certainly have advantages and disadvantages of each.
\end{abstract}

Keywords: Takhrîj al-Hadîth, Ontology , Axiology , Hadith Sciences 


\section{Pendahuluan}

Menelusuri hadis sampai pada sumber aslinya tidak semudah menelusuri ayat Al-Qur'an. Sebab untuk menelusuri ayat Al-Qur'an cukup diperlukan sebuah kitab kamus Al-Qur'an, misalnya kitab alMu'jam al-Mufahras li Alfâdh al-Qur'ân al-Karîm susunan Muhammad Fûad 'Abd al-Bâqî, dan sebuah kitab rujukan berupa mushaf Al-Qur'an. Sedangkan guna menelusuri hadis, tidak cukup hanya dengan sebuah kamus dan sebuah kitab rujukan yang berupa kitab hadis yang disusun oleh mukharrij-nya. Ini dikarenakan hadis terhimpun dalam banyak kitab hadis. ${ }^{1}$

Berangkat dari noktah tersebut, para mubaddithîn menformulasikan sebuah metode guna melacak hadis sampai ke sumber aslinya. Yang mana tujuan akhirnya tentu untuk mengetahui maqbûl atau mardûd-nya suatu hadis. Formulasi tersebut dinamakan takbrij al-hadith.

Melalaui takhrij al-hadith seorang peneliti hadis akan digiring menuju pintu masuk bagi kegiatan penelitian hadis. Dimana di dalamnya ia akan mengetahui asal-usul riwayat hadis yang akan diteliti, berbagai periwayat yang meriwayatkan hadis tersebut,dan ada atau tidaknya korroborasi (shâbid dan mutâbi) dalam sanad hadis yang ditelitinya. ${ }^{2}$

Dengan titik tolak seperti dipaparkan di atas, tulisan ini akan mencoba untuk sekilas menguraikan tentang pengertian, manfaat, dan metode takhrîj al-hadîth.

\section{Pengertian Takhrîj Al-Hadîth}

Secara etimologis, kata takhrij berasal dari kata kharraja, yang berarti al.zuĥेr (tampak) dan al-burûz (jelas). ${ }^{3}$ Takbrij juga bisa berarti al-istinbât (mengeluarkan), at-tadrîb (meneliti), dan at-taujih (menerangkan). ${ }^{4}$

Sedangkan kata takhrij, menurut istilah ahli hadis, mempunyai beberapa pengertian:

\footnotetext{
${ }^{1}$ M. Syuhudi Ismail, Metodologi Penelitian Hadis Nabi, (Jakarta: Bulan Bintang, 1992), 4546.

${ }^{2}$ Setidaknya tiga alasan tersebutlah -yang menurut M. Syuhudi Ismail- merupakan alasan utama yang mendasari pentingnya kegiatan takhrîj al-hadìth. M. Syuhudi Ismail, Metodologi Penelitian..., 44-45.

3 Louis Ma'luf, al-Munjîd fi al-Lughah wa al-'Alâm, (Beirut: Dâr al-Mashrq, t.t.), 172; Ahmad Warson Munawwir, Kamus al-Munawwir, (Yogyakarta: Pondok Pesantren alMunawwir, 1986), 356.

${ }^{4}$ Al-Fayrûz Abadi, al-Qâmûs al-Mubît, Vol. I, (Kairo: al-Maimûniyyah, 1313 H), 192; Ibn Manẓûr, Lisân al-'Arab, Vol. II (Beirut: Dâr al-'Ilm), 249.
} 
1) Mengemukakan hadis pada orang banyak dengan menyebutkan periwayatannya dengan sanad lengkap serta dengan penyebutan metode yang mereka tempuh. Kegiatan takhrij al-hadith semacam ini dilakukan oleh para penghimpun dan penyususn kitab hadis, seperti al-Bukhârî yang menyusun kitab hadis Sabîh al-Bukhârî. ${ }^{5}$

2) Mengemukakan berbagai hadis yang telah dikemukakan oleh para guru hadis atau berbagai kitab yang mereka susunan berdasarkan riwayatnya sendiri atau para gurunya atau para temannya atau orang lain, dengan tetap mencantumkan siapa periwayatnya dari para penyususn kitab ataupun karya yang dijadikan sumber acuan. Kegiatan ini seperti yang dilakukan oleh Imam al-Baihaqî yang banyak mengambil hadis dari kitab as-Sunan karya Abû al-Ḥasan al-Bașrî asSafar, lalu al-Baihaqî mengemukakan sanad-nya sendiri. ${ }^{6}$

3) Menunjukkan asal-usul suatu hadis dan mengemukakan sumber pengambilannya dari berbagai kitab hadis yang disusun mukharrij-nya langsung. Kegiatan takhrij al-badith seperti ini dilakukan oleh para penghimpun hadis, misalnya Ibn Hajar al-Asqalânî yang menyusun kitab Bulügh al-Marâm?

4) Mengemukakan hadis berdasarkan kitab tertentu dengan disertakan metode periwayatan dan sanad-nya serta penjelasan keadaan para periwayatnya serta kualitas hadisnya. Pengertian takhrij al-badith semacam ini dilakukan oleh Zain ad-Dîn 'Abd ar-Rạmân ibn alHusain al-'Irâqî yang melakukan takhrîj terhadap hadis-hadis yang termuat dalam kitab Ibyâ' 'Ulüm ad-Dîn karya al-Ghazâlî, dengan bukunya Ikbbâr al-Ihyâ' bi Akbbâr al-Ihyâ..

5) Mengemukakan letak asal suatu hadis dari sumbernya yang asli, yakni berbagai sumber kitab hadis dengan dikemukakan sanad-nya secara lengkap untuk kemudian dilakukan penelitian terhadap kualitas hadis tersebut. ${ }^{9}$

Berdasarkan beberapa pengertian terminologis di atas, maka pengertian takhrij yang sesuai dengan pembahasan di dalam makalah ini adalah kategori pengertian takhrij yang kelima, yakni menunjukkan tempat hadis pada sumber aslinya, dimana hadis tersebut telah

\footnotetext{
${ }^{5}$ M. Syuhudi Ismail, Metodologi Penelitian..., 42.

${ }^{6}$ Ibid., 43.

7 Ibid.

8 Ibid.

${ }^{9}$ Ibid.
} 
diriwayatkan lengkap dengan sanad-nya, untuk kemudian dijelaskan derajatnya jika diperlukan. ${ }^{10}$

\section{Manfaat Takhrîj Al-Hadîth}

Manfaat kegiatan takhrîj al-hadîth adalah: ${ }^{11}$

1. Mengetahui sumber hadis berdasarkan kitab utama (primer) hadis tersebut.

2. Mengetahui semua jalur riwayat hadis.

3. Mengetahui rangkaian silsilah hadis.

4. Mengetahui kualitas jalur hadis yang lebih baik di antara banyaknya jalur riwayat hadis.

5. Menaikkan kualitas suatu hadis yang da'if menjadi hasan atau șabị̣̂ jika ada shawâhid atau tawâbi'.

6. Mengetahui penilaian mubaddith terhadap kualitas suatu hadis.

7. Menghilangkan adanya kesan tadlis pada hadis mu'an'an.

8. Membedakan para perawi hadis yang memiliki nama yang sama.

9. Menjelaskan ungkapan yang samar dari redaksi suatu hadis baik pada rawi maupun matn hadis itu sendiri.

10. Menghilangkan kekhawatiran adanya hadis yang tercampur oleh perkataan perawi.

11. Membatasi nama perawi.

12. Mengetahui kelengkapan peristiwa yang diliputi suatu hadis.

13. Menjelaskan makna kata-kata gharîb pada suatu matn hadis.

14. Menghilangkan unsur shadhdh.

15. Menjelaskan hadis yang terkadang diriwayatkan sepotong-sepotong.

16. Menjelaskan hadis yang redaksinya kurang.

17. Mengetahui periwayatan hadis dengan matn.

18. Mengetahui waktu dan tempat terjadinya hadis.

19. Mengetahui asbâb an-nuðûl hadis.

20. Mengetahui ada atau tidaknya nâsikh dan mansûkk pada suatu hadis.

21. Membedakan antara periwayatan secara lafal dan periwayatan secara makna.

\footnotetext{
10 Maḥmûd al-Ṭaḥhân, Usûl at-Takhrîj wa al-Dirâsât al-Asânid, (Beirut: Dâr al-Qurân alKarîm, 1978), 12.

11 Abû Muhammad 'Abd al-Mahd ibn 'Abd al-Qâdir ibn 'Abd al-Hâdî, Țuruq Takhrîj Hadîth Rasûlillâh Saw., (Kairo: Dâr al-Itisâm, T.T.), 11-14;
} 


\section{Metode Takhrîj Al-Hadîth}

Secara garis besar ada dua cara dalam melakukan takhrij al-hadith, yaitu pertama, takhrij al-hadith dengan menggunakan kitab-kitab hadis atau kamus. Kedua, takhrij al-hadith dengan menggunakan perangkat komputer. $^{12}$

1) Takbrij al-Hadîth Melalui Kitab-kitab Hadis atau Kamus

Ada lima metode yang bisa digunakan dalam kegiatan takbrij albadith. Masing-masing mempunyai kelebihan dan kekuragan tersendiri, meski tujuan akhirnya tetap sama, yakni menelusuri hadis sampai sumbernya yang asli.

Kelima metode takhrij al-hadith tersebut, adalah:

a) Takbrij berdasarkan awal kata dari matn hadis

Guna melakukan metode ini, terlebih dahulu harus diketahui seluruh atau sekurang-kurangnya awal suatu matn hadis. Kemudian dilihat huruf awal kata yang paling awal dari matn hadis tersebut. ${ }^{13}$

1) Kitab-kitab yang diperlukan ${ }^{14}$

a) Kitab-kitab yang memuat hadis-hadis masyhur di masyarakat:

- At-Tadbkirah fí al-Ahâdis al-Mushtabirah karya Badr ad-Dîn Muḥammad ibn 'Abd Allâh az-Zarkashî.

- Al-Laâli al-Manș̂urah al-Ahâdith al-Mushtabirah karya Ibn Hajar al-Asqalâni.

- Al-Maqậșid al-Hasanah fî Bayân Kathîr min al-Ahâdith alMushtabirah 'alâ al-Alsinah karya as-Sakhâwî.

- Tamyîz at-Tayyib min al-Khabîs fî mâ Yadûr 'alâ Alsinah anNâs min al-Hadîth karya Abd ar-Raḥmâ ibn 'Alîibn adDibâ ash-Shaybânî.

- Ad-Durar al-Muntașirah fî al-Abâdis al-Mushtahirah karya Jalâl ad-Dîn 'Abd ar-Raḥmân as-Suyuṭ̂i.

b) Kitab-kitab yang disusun secara alfabetis:

- Al-Jamî̀ aș-Saghîr min Hadîthal-Bashîr an-Nadhîr karya Jalâl ad-Dîn 'Abd ar-Raḥmân Ibn Abî Bakr as-Suyuṭ̂i.

- Al-Jamî al-Kabîr karya as-Suyuṭ̂i.

\footnotetext{
12 Suryadi dan Muhammad Alfatih Suryadilaga, Metodologi Penelitian Hadis, (Yokyakarta: Teras, 2003), 38.

13 Ibn Hajar al-Asqalânî, Sharh Nukhbah al-Fiker fì Mustalăh Abl al-Athar, (Cairo: Dâr atTibâ'ah al-Muhammadiyah, t.t.)

14 Maḥmûd al-Ṭaḥhân, Ușûl at-Takhrîj..., 62-89; 'Abd al-Mahd, Turuq Takbrîj..., 27-79.
} 
- Al-Fath al-Kabîr fî Damm az-Ziyâdab ilâ al-Jamî̀ aṣ-Ṣaghîr karya Yûsuf an-Nabhanî.

- Al-Jamî al-Az̧bâr min al-Hadîth an-Nabî al-Anwâr karya 'Abd ar-Raûf ibn Tâj ad-Dîn 'Alî al-Hâdî al-Munawî.

- Kanz al-Haqâaiq fi Hadîth Khair al-Khalâiq karya 'Abd arRaûf ibn Tâj ad-Dîn 'Alî al-Hâdî al-Munawî.

c) Kamus yang disusun pengarangnya untuk kitab tertentu:

- Hady al-Bârî ilâ Tartîb Abâdîth al-Bukhârî untuk kitab Ṣabị̂̉ Bukhârî.

- Mujjam al-Alfâz wa lâ Siyyamâ al-Gharîb minhâ untuk kitab Sabîh Muslim.

- Miftâhb ạ̦-Ṣabîhain untuk Ṣabîhain.

- Miftâh al-Muwatța' untuk kitab al-Muwatța'.

- Miftâh Sunan Ibn Mâjab untuk kitab Sunan Ibn Mâjah.

- Miftâh at-Tartîb li Abâdîth Târîkh al-Khatî́b untuk kitab Târikh al-Baghdâdî.

2) Kelebihan dan kekurangan ${ }^{15}$

Dengan hanya mengetahui lafadz awal matn, penelusur hadis dapat menemukan sumber asli hadis yang dicari lengkap dengan sanad dan matn-nya. Hanya saja kekurangannya adalah peneliti hadis masih harus bekerja keras karena tidak dicantumkan nomor bab ataupun halaman dari hadis tersebut pada kitab tertentu.

b) Takhrij berdasarkan lafal pada matn hadis

Metode ini dilakukan dengan cara menelususri hadis berdasarkan huruf salah kata (ism/fi'il) dasar pada lafadz yang ada pada matn hadis. ${ }^{16}$

1) Kitab-kitab yang diperlukan ${ }^{17}$

Referensi yang paling representatif untuk metode ini adalah kamus karangan Arnold John Wensick, al-Mu'jan al-Mufahras li Alfầ. al-Hadìth an-Nabawî, yang dialihbahasakan ke dalam Bahasa Arab oleh Muḥammad Fuad 'Abd al-Bâqî. Kitab ini merupakan kitab kamus dari sembilan kitab hadis (kutub at-

\footnotetext{
15 Suryadi, Metodologi Penelitian..., 44.

16 Ibn Hajar, Sharb Nukbbah..., 56.

${ }^{17}$ Maḥmûd al-Ṭaḥhân, Usûl at-Takbrij..., 90-105; 'Abd al-Mahd, Turuq Takhrîj..., 83-101.
} 


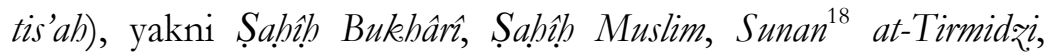
Sunan an-Nasâi, Sunan Abî Dâwud, Sunan Ibn Mâjah, Musnad Ahmad Ibn Hanbal, Munvațta' Mâlik, dan Sunan ad-Dârimî.

Untuk Musnad Abmad (حم) hanya disebutkan juz serta halamannya; Sạhị̂h Bukhârî (p) dan al-Muwatța' (b) disebutkan

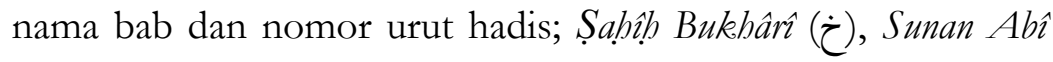
Dâwud (د), Sunan at-Tirmidr̨i (ت), Sunan an-Nasâi (ن), Sunan Ibn Mâjah (ج), serta Sunan ad-Dârimî (د) disebutkan nama bab serta nomor urut babnya.

Kitab lain yang disusun dengan metode ini adalah Fibrîs Șabîh Muslim karya Mụammad Fuad 'Abd al-Bâqî, dan Fibrîs Sunan Ab̂̀ Dâwud karya Ibn Bayumi yang diuraikan oleh Mạ̣mûd Khțtah as-Subkî.

2) Kelebihan dan kekurangan ${ }^{19}$

Kelebihan dari metode ini ialah:

a) Dengan menggunakan sebagian lafadznya saja (ism/fi'i baik di awal, tengah, maupun di akhir matn, hadis dapat ditelusuri sumber aslinya dengan cepat. Karena bersama kitab rujukan disertakan nama bab, nomor bab, atau nomor hadis, serta nomor juz dan halamannya.

b) Memudahkan untuk mencari hadis-hadis dengan sumbernya dalam matn yang sama atau hampir sama.

Sedangkan kekurangannya antara lain:

a) Penelusur hadis yang memakai metode ini harus mengetahui kata asal dari lafadz yang diketahui.

b) Kamus ini hanya memuat hadis-hadis yang termuat dalam kutub at-tis'ah. Sehingga jika hadis yang diteliti tidak terdapat dalam kutub at-tis'ah, maka hadis tersebut tidak akan ditemukan.

c) Metode ini tidak bisa dipergunakan jika yang diketahui adalah ism damîr, nama orang, atau kata kerja yang sering dipergunakan.

\footnotetext{
18 Secara umum kitab dalam bentuk sunan berisikan masalah-masalah hukum yang marfú' dan penyusunannya didasarkan pada bab fikih. Nûr ad-Dîn Itr, Manhaj an-Naqd fî̀ 'Ulûm al-Hadîth, Beirut: Dâr al-Fikr, 1992), 199-200.

${ }^{19}$ Suryadi, Metodologi Penelitian..., 44-45.
} 
d) Tidak secara langsung diketahui rawi awal hadis yang dimaksud.

c) Takbrij berdasarkan perawi pertama

1) Kitab -kitab yang diperlukan

a) Kitab-kitab musnad ${ }^{20}$

- Musnad A.mmad ibn Hanbal

- Musnad Abî Baker 'Abd Allâh ibn az-Zubair al-Humaidi

- Musnad Abî Dâwud at-Tayâlisî

- Musnad Abî Ishâqq Ibrâhîm ibn Naṣr

- Musnad Asad ibn Mûsâal-Umawñ

- Musnad Yabya ibn 'Abd al-Humaid al-Hamanî

- Musnad Musaddad ibn Musarbad as-Asadî al-Bașrî

- Musnad Abî Yalâ Abmad ibn 'Alî al-Musanî a-Mausû́lî

- Musnad Aid ibn Humaid

- Musnad Ubaidillah ibn Mûsâ al-Aisî

- Musnad Nu'aim ibn Hammâd, dan sebagainya

b) Kitab-kitab mu'jam ${ }^{21}$

- Al-Mu'jam al-Kabîr karya Abû al-Qâsim Sulaimân ibn Ahmad at-Ṭabaranî.

- Al-Mujam al-Ausat karya Abû al-Qâsim Sulaimân ibn Aḥmad at-Tabaranî.

- Al-Mu'jam ạ̦-Ṣaghîr karya Abû al-Qâsim Sulaimân ibn Aḥmad at-Ṭabaranî.

- Mu'jam aṣ-Sạâabah karya Aṇmad ibn 'Alî ibn Lalî alHamdânî.

- Mu'jam aṣ-Sahâbab karya Abû Ya'lâ Aḥmad ibn 'Alî alMusilitî.

c) Kitab-kitab atráf ${ }^{2}$

\footnotetext{
${ }^{20}$ Kitab musnad adalah kitab yang disusun pengarangnya berdasarkan nama perawi awal, baik dari kalangan sahabat maupun tabiin.

Adapun urutan nama dalam kitab musnad tidaklah seragam. Ada yang diurutkan berdasarkan alfabetis, berdasarkan yang lebih utama, berdasarkan yang lebih dulu masuk Islam, berdasarkan kabilah atau wilayah daerahnya. Nûr ad-Dîn, Manhaj an-Naqd..., 201. ${ }^{21}$ Mu'jam adalah hadis adalah kitab-kitab hadis yang disusun berdasarkan sahabat, guru, atau negeri-negeri tertentu. Nûr ad-Dîn, Manhaj an-Naqd..., 201.

${ }^{22}$ Kata atrâf merupakan jama' dari kata tarf yang berarti sudut. Dalam kajian ini atrâf diartikan sebagai kitab-kitab hadis yang disusun dengan menyebut bagian hadis yang menunjukkan keseluruhannya, kemudian disebutkan sanad pada kitab sumbernya. Ibid.
} 
- Ațrâf aṣ-Ṣabîhain karya Abû Mas'ûd Ibrâhîm ibn Muhammad ad-Dimashqî

- Atrấf ạ̦-Ṣabîhain karya Abû Muhammad Khalâf ibn Muhammd al-Wâsitîi.

- Atrâf al-Masânid al-'Ashrah karya Abû al-'Abbâs Aḥmad ibn Muhammad al-Busairî.

- Ithâf al-Mahrah bi Atrâf al-'Ashrah karya Aḥmad ibn Alî ibn Hajar al-Asqalânî.

- Zakhair al-Mawârith fî ad-Dilâlah 'alâ Mawâdi al-Hadîth karya 'Abd al-Ghanî an-Nabilisî.

2) Kelebihan dan kekurangan ${ }^{23}$

Kelebihan menggunakan metode ini adalah:

a) Dapat mengetahui semua hadis yang diriwayatkan sahabat tertentu dengan sanad dan matn-nya secara lengkap.

b) Memudahkan untuk menghafal dan mengingat hadis yang diriwayatkan oleh sahabat tertentu.

Sedangkan kekurangan dari metode ini:

a) Membutuhkan waktu yang relatif lama untuk menemukan sahabat tertentu dengan hadisnya-khusus untuk kitabkitab yang disusun tidak secara alfabetis.

b) Bervariasinya kualitas hadis yang terkumpul karena tanpa penyeleksian sehingga ada yang șahîh, hasan, dan da'if.

d) Takhrij berdasarkan tema hadis

Metode ini dilakukan dengan menelusuri hadis berdasarkan temanya, apakah temanya bersifat umum ataukah khusus seperti fikih, akhlak, tahsir, dan sebagainya. ${ }^{24}$

1) Kitab-kitab yang diperlukan

a) Kitab-kitab jawâmi ${ }^{25}$

- Al-Jâmi' aṣ-Sabîh karya Abû 'Abd Allâh Muhammad ibn Ismâil al-Bukhârî.

- Al-Jâmi’ baina ạ̦-Ṣabîhain karya Ismâil ibn Ạ̣mad.

- Al-Jâmi’ ạ̦-Ṣabị̂h karya Imâm Muslim.

\footnotetext{
23 Suryadi, Metodologi Penelitian..., 42.

${ }^{24}$ Ibn Hajar, Sharb Nukbbah..., 61.

25 Jawâmi' biasanya berisikan tentang masalah-masalah keagamaan yang disusn berdasarkan tema. Adapun tema-tema yang biasanya termakstub dalam jawâmi' antara lain akidah, manaqib, tanda-tanda hari kiamat dan sebagainya. Nûr ad-Dîn, Manhaj anNaqd..., 197-199.
} 
- Al-Jâmi' baina ạ̦-Ṣabîhbain karya Muhammad ibn Abî Naṣr al-Humaidî.

b) Kitab-kitab mustakbraj ${ }^{26}$

- Mustakbraj Șabîh al-Bukhârî karya al-Gițifi.

- Mustakbraj Șabî̉ Muslim karya Abû Awânah al-Isfirâyinî.

- Mustakbraj Sabîh Sabîhain karya Abû Nu'aim al-Aṣbịhanî.

c) Kitab-kitab majâmi ${ }^{27}$

- Al-Jam baina aṣ-Ṣabîhbain karya as-Saghanî al-Hasan ibn Muhammad.

- Al-Jam baina aș-Ṣabị̂hain karya 'Abd Allâh ibn Abî Nașr Futûh al-Humaidî.

- Al-Jam baina Ușûl as-Sittah karya Abû Hasan Râzim ibn Muâwiyah.

- Al-Jam baina Ușûl as-Sittah karya ibn al-Athîr.

d) Kitab-kitab mustadrak ${ }^{28}$

- Al-Mustadrak karya al-Hâkim

- Al-Mustadrak karya Abû Dhazz al-Harawî.

e) Kitab-kitab qawâid ${ }^{29}$

- Miṣbậb ą-Zujâjah fi Zawâid Ibn Mâjah karya al-Bușairî.

- Fawaid al-Muntaqâ li Zawâid al-Baihaqî karya al-Bușairî.

- Ittihâf as-Saddah al-Mahrah al-Khairah bi Zawâid al-Masânid al-'Ashrah karya al-Bușairî.

f) Kitab Miftâh Kunûz as-Sunnah

Kitab ini disusun oleh Arnold John Wensick dan dialihbahasakan ke dalam Bahasa Arab oleh Muhammad Fuad 'Abd al-Bâqî. Kitab yang dijadikan rujukan berjumlah empat belas kitab, yakni Șabị̂ Bukbârî, Șabîh Muslim, Sunan at-Tirmidř, Sunan an-Nasâi, Sunan Abî Dâwud, Sunan Ibn Mâjah, Muwatta' Mâlik, Musnad A.bmad Ibn Hanbal, Musnad Abî Dâwud aț-Tayâlisî̀, Sunan ad-Dârimî̀, Musnad Zaid ibn 'Alì, Sîrab Ibn Hishâmi, Maghẫị̂ al-Wâqidî, Țabaqât Ibn Sad.

\footnotetext{
${ }^{26}$ Mustakhrâj merupan kitab yang berisi hadis yang telah di takhrîj dari kitab tertentu. (Ibid).

27 Majâmi' merupakan jamak dari mu'jam. Lihat footnote nomor 21.

${ }_{28}$ Mustadrak berisi hadis-hadis yang dilupakan dan tidak dibukukan oleh kitab-kitab sebelumnya. Dan guna menguatkan nilai-nilai hadis tersebut, penyusun mustadrak berusaha mencarikan sandaran-sandaran lain. (Ibid., 200).

${ }_{29}$ Zawâid merupakan kitab yang disusun untuk menghimpun hadis-hadis yang tidak masuk dalam kitab lain. (Ibid., 209).
} 
2) Kelebihan dan kekurangan ${ }^{30}$

Kelebihan dari metode ini adalah banyaknya hadis yang ditemukan pada tema tertentu karena sumber yang dijadikan rujukan kitab ini cukup banyak, yakni 14 buah.

Adapun kekurangan dari metode ini adalah sulitnya menentukan suatu potongan matn hadis termasuk pada bagian tema apa. Sebab sangat besar kemungkinan adanya perbedaan persepsi antara penyusun kitab dan penelusur hadis terkait dengan relevansi tema.

e) Takhrij berdasarkan sifat lahiriah hadis

Penelusuran hadis dengan metode ini dapat ditempuh dengan mengamati matn dan sanad hadis secara seksama. Sehingga muncul beberapa kategori, diantaranya:

1) Matn yang mengandung kerusakan makna hadis, menyelisihi $\mathrm{Al}-$ Qur'an, ataupun redaksi palsu. Kitab-kitab yang bisa menjadi rujukan adalah:

- Al-Maudû̀'ât aș-Sughrâ karya 'Alî al-Qâri.

- Tanzîh ash-Sharìah al-Marfü'ab an al-Ahâdîth al-Maud̂̀'ah, karya al-Kinânî. ${ }^{31}$

2) Matn yang berupa hadis qudsi. Di antara kitab-kitab rujukannya adalah:

- Mishkâh al-Anwâr karya Muhy ad-Dîn Muhammad ibn 'Alî ibn 'Arabî al-Khâtimî.

- Al-Ittibâfât as-Saniyyah bi al-Ahâdîth al-Qudsiyyah karya 'Abd Raûf al-Munawi. ${ }^{32}$

3) Sanad yang rawinya meriwayatkan hadis dari anaknya. Salah satu kitab rujukannya ialah Riwâyah al-Âbâ 'an al-Âbâ karya Abû Bakr Aḥmad ibn 'Alî al-Baghdâdî.

4) Sanad hadis yang musalsal dengan kitab rujukannya al-Musalsal alKubrâ karya as-Suyûtî. ${ }^{34}$

5) Sanad yang mursal. Di antara kitab-kitab rujukannya adalah:

- Al-Marâsil karya Abû Dâwud.

- As-Sïistânî karya ar-Râzî. ${ }^{35}$

\footnotetext{
30 Suryadi, Metodologi Penelitian..., 47.

31 Jamâl ad-Dîn, Muhammad al-Qâsimî, Qawaiid at-Tạ̣dîth min Funûn Mustalab al-Hadîth, (Beirut: Dâr Ihyầ’ as-Sunnah an-Nabawiyyah, t.t.), 156.

32 Ibid.

${ }^{33}$ Ibid., 157.

${ }^{34}$ Ibid., 157.
} 
Kelebihan dari metode ini adalah selain menemukan hadis yang dicari dalam kitab rujukan, juga ditemukan penjelasan tambahan dari penyusunnya. Sedangkan sisi negatifnya adalah perlunya pengetahuan yang mendalam bagi penelusur hadis untuk mengetahui keadaan sanad dan matn hadis. ${ }^{36}$

2) Takbrîj al-Hadîth Melalui Perangkat Komputer ${ }^{37}$

Cara melakukan takhrij al-hadith dengan menelusuri dan membaca kitab-kitab hadis atau kamus sangat baik, namun memerlukan waktu yang lama. Untuk mempercepat proses penelusuran dan pencarian hadis, jasa komputer dengan progam Mausû'ah al-Hadîth ash-Sharîf alKutub at-Tis'ah bisa digunakan. Progam ini merupakan software komputer yang tersimpan dalam compact disk read only memory (CDROM). ${ }^{38}$

Progam ini memuat seluruh hadis yang terdapat di dalam al-kutub

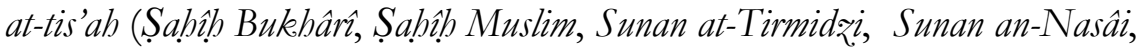
Sunan Ab̂̀ Dâwud, Sunan Ibn Mâjah, Musnad Abmad Ibn Hanbal, Muwatța' Mâlike, dan Sunan ad-Dârimî) lengkap dengan sanad dan matnnya. Di samping itu progam ini juga memuat data-data tentang biografi, daftar guru dan murid, al-jarb wa at-ta'dîl dari semua periwayat hadis yang ada di dalam al-kutub at-tis'ah. Progam iini juga dapat menampilkan skema sanad hadis, baik satu jalur maupun skema semua jalur periwayatan.

Ada delapan macam cara yang bisa digunakan untuk menelusuri hadis-hadis yang terdapat dalam kutub at-tis'ah melalui bantuan progam. Kedelapan cara penelusuran hadis tersebut adalah:

a. Memilih lafadz yang terdapat dalam daftar lafadz yang sesuai dengan hadis yang dicari.

b. Mengetik salah satu lafadz dalam matn hadis.

c. Berdasarkan tema kndungan hadis.

d. Berdasarkan kittâb dan bâb sesuai dengan yang ada dalam kitab aslinya.

e. Berdasarkan nomor urut hadis.

f. Berdasarkan nama periwayatnya.

\footnotetext{
35 Ibid.

36 Suryadi, Metodologi Penelitian..., 48.

${ }^{37}$ Ibid., 49-50.

38 Selain progam Mausû'ah al-Hadith ash-Sharif al-Kutub at-Tis'ah, seorang peneliti juga dapat menggunakan CD-ROM al-Maktabah al-Alfiyyah li al-Sunnah al-Nabawiyyah. Namun progam Mausû́ah dirasa lebih lengkap dibanding Maktabah.
} 
g. Berdasarkan aspek tertentu dalam hadis.

h. Berdasarkan takhrij hadis.

\section{Penutup}

Dapat mengetahui semua hadis yang diriwayatkan sahabat tertentu dengan sanad dan matn-nya secara lengkap. Memudahkan untuk menghafal dan mengingat hadis yang diriwayatkan oleh sahabat tertentu. Sedangkan kekurangan dari metode ini: Membutuhkan waktu yang relatif lama untuk menemukan sahabat tertentu dengan hadisnya-khusus untuk kitab-kitab yang disusun tidak secara alfabetis. Bervariasinya kualitas hadis yang terkumpul karena tanpa penyeleksian sehingga ada yang șahtĥ, hasan, dan da'if. 


\section{Daftar Pustaka}

Asqalânî (al), Ibn Hajar. Sharh Nukbbah al-Fikr fî Mustalạh Abl al-Athar. Cairo: Dâr at-Tibâ'ah al-Muhammadiyah, t.t.

Azami, M. M. Studies in Hadith Methodology and Literature. Indianapolis: American Trust Publications, 1977.

Hâdî (al), Abû Muhammad 'Abd al-Mahd ibn 'Abd al-Qâdir ibn 'Abd. Țuruq Takbrîj Hadìth Rasûlillâh Saw. Kairo: Dâr al-Itișâm, t.t.

Ismail, M. Syuhudi. Metodologi Penelitian Hadis Nabi. Jakarta: Bulan Bintang, 1992.

Itr, Nûr ad-Dîn. Manbaj an-Naqd fî̀ Ulùm al-Hadîth. Beirut: Dâr al-Fikr, 1992.

Khâțib (al), Muhammad 'Ajjâj. 'Usûul al-Hadîth 'Ulûmubu wa Muṣtalạubu. Beirut: Dâr al-Fikr, 1989.

Ma'luf, Louis. Al-Munjî̀ fî al-Lughah wa al-'Alâm. Beirut: Dâr al-Mashrq, t.t.

Munawwir, Ahmad Warson. Kamus al-Munawnir. Yogyakarta: Pondok Pesantren al-Munawwir, 1986.

Șâliḥ (al), Șubhii. 'Usûul al-Hadîth wa Muștalabubu. Beirut: Dâr al-'Ilm li alMalâyîn, 1988.

Suryadi dan Muhammad al-Fatih Suryadilaga. Metodologi Penelitian Hadis. Yokyakarta: Teras, 2003.

Ṭaḥhân (al), Mahmmûd. Usûul at-Takhrij wa ad-Dirâsât al-Asânid. Beirut: Dâr Al-Qurân al-Karîm, 1978. 